\title{
Sunil Yapa's Your Heart is a Muscle the Size of a Fist: Protest, Fiction and the Ethics of Care ${ }^{1}$
}

\section{Isabel Alonso-Breto}

University of Barcelona

\begin{abstract}
Sunil Yapa's politically engaged first novel vindicates the massive pacific protests that occurred during five days in Seattle in November-December 1999. These protests were summoned against the World Trade Organization summit. The novel responds to the wish to inscribe in the history of fiction a crucial event which would inspire and inflect the later anti-globalization movement and protests, and which according to some has not yet received the attention it deserves by media or criticism. This article discusses Yapa's work in the light of the Ethics of Care, and develops an exegesis, which, incorporating elements of Hardt and Negri's ideas about the Multitude, understands the novel mainly as a reflection of the crucial preoccupation that humans have for other human beings, and the innate wish to actively take care of the Other and improve his or her life conditions.
\end{abstract}

Keywords: Sunil Yapa, social protest, Ethics of Care, protest fiction, World Bank Literature

Your heart is a muscle the size of your fist.

Keep on loving. Keep on fighting.

And hold on, and hold on,

Hold on for your life

Ramshackle Glory, 2010-2016

1 This paper benefitted from MICINN funding, Ref. FFI2015-63739-P. 


\section{Introduction}

Your Heart is a Muscle the Size of a Fist is Sunil Yapa's politically engaged first novel from 2016. It is a work that vindicates the massive pacific demonstrations that lasted for five days in Seattle in November-December 1999 and which were organized to protest against the World Trade Organization (WTO) summit. This event gathered some fifty-thousand demonstrators (somewhat less according to other sources, see Holden 2008), who came mostly from the United States but also from other countries. A multitude of groups with different but connected agendas joined to reject the advancement of a globalization based on unbridled capitalism, which, as denounced by scholars and intellectuals, privileges the economic benefits of transnational corporations and leaves aside the elementary rights of workers and ordinary people. This paper contends that the novel responds to the wish to inscribe in the history of fiction a crucial event which would inflect later anti-globalization movements and protests, and which according to some has not yet received the attention it deserves by media or criticism: "America seemed to decide that we had much more important things to protest about, and the Seattle protesters have been largely forgotten in our pop media culture" (Smith 2014). Notwithstanding this statement, some literary and documentary works have portrayed the episode before Sunil Yapa's work, such as Robert Newman's anti-globalization novel The Fountain at the Center of the World (2003), although in fiction none has focused so centrally on the so-called 'Battle of Seattle' as Yapa's. Cinema was quicker to react than literature, Stuart Townsend's film Battle in Seattle being released in 2007. Soon after the events, several documentaries displaying various degrees of creativity were released, such as 30 Frames a Second: The WTO in Seattle (Rustin Thompson 2000) and This is What Democracy Looks Like (Jill Friedberg and Rick Rowley 2000). Adding to these documents was the collection edited by David and Rebecca Solnit The Battle of the Battle of Seattle (2009), which approaches the events from different critical perspectives.

Besides contending that the novel succeeds in fictionalizing the historical episode of the Battle of Seattle, this paper aims to demonstrate that this work embodies a productive articulation of the dynamics of love and care for others which move human beings. It will do so by analyzing the novel under the lens of what has been termed the Ethics of Care, a line of thought and action, which, surprisingly, has not been (at least extensively, and to my knowledge) connected to literary studies so far. 


\section{The 'Battle of Seattle' and the Power of the Multitude}

Recording the Seattle protests and historicizing them in fictional form, Your Heart is a Muscle the Size of a Fist ${ }^{2}$ appears as a necessary work filling a gap in the memory of social protest. Colum McCann, who was Yapa's lecturer in the Creative Writing MFA he completed after graduating in Economic Geography, describes Your Heart on the cover as "a Molotov cocktail to light up the dark". Like McCann, most reviewers have applauded the novel: "a fantastic debut" (Charles 2015), "a gorgeous riot against injustice" (Ditum 2016), "the novel reveals, almost despite itself, a deeper, quieter knowledge of 'the whole ugly beautiful thing' that's the world" (Hendrix 2016), "pace and control over what could easily have become an unwieldy mess" (Scholes 2016), "fast-paced and unflinching" (The New Yorker 2016). A few others have not been so enraptured by what they term the novel's "clobbering emotion and occasional sentimentality" (Winik 2016), its "muddled [prose] as Yapa jumps from voice to voice" (Limprecht 2016), or a too flowery style and "amateurish" craft (Schaub 2016). However, no reviewer has denied its political importance. In this regard, Your Heart is a protest novel. Yet the author himself further categorizes his work as 'World Bank Literature', that is, "fiction that attends to and attempts to decipher our 21 st-century global tangle, in particular by noticing economic systems, disparities, and pressure points" (Patrick 2016), as Peter Mountford, the author of two novels with connected themes (A Young Man's Guide to Late Capitalism 2011, and The Dismal Science 2014), has defined it (See also Kumar 2002).

In 1999, the World Trade Organization was a relatively new institution. It had been founded in 1995, heir to the General Agreement on Trade and Tariffs (GATT), signed after World War Two, when the International Monetary Fund and the World Bank were also founded. As Kit Oldham explains, these institutions were created with the aim of facilitating recovery from the devastation created by war and the preceding Great Depression:

During the Depression, many countries had responded to the economic downturn by imposing high tariffs on foreign imports and other measures that limited or regulated international trade. Postwar leaders in the U.S. and Europe believed that these protectionist measures had further damaged the economy and they designed the GATT to reduce tariffs and other barriers to what they termed 'free trade'. (Oldham 2009)

2 Page numbers referring to the novel will be provided without further reference. The novel will be referred to through the shortened form Your Heart. 
In 1999 the GATT had grown into an ever more powerful WTO, and many voices warned of a globalization, which increased inequity in the distribution of wealth and the means of production. Those thousands of persons gathered in Seattle saw deepening inequalities favored by the lenience of international law in transnational trade and finances. This was a pioneering movement, bringing together groups with different ideologies in a protest which, precisely for this reason, can be labelled as global, even if most protesters were actually from the US.

Two factions thus confronted each other in the Battle of Seattle; the institutional representatives against the people:

Most governments around the world, leading multinational corporations, and virtually all of Washington state's political and business leaders supported the WTO and 'free trade', which they argued benefited society by promoting economic growth... [versus] international and local labor unions, environmental groups, and activists for many other causes [who] increasingly condemned the WTO for favoring corporate interests over social and environmental concerns. (Oldham 2009)

The organizers managed to bring together a huge number of heterogeneous groups, including

unions worried about competition from cheap foreign labor, environmentalists worried about the outsourcing of polluting activities, consumer protection groups worried about unsafe imports, labor rights groups worried about bad working conditions in other countries, and leftists of various stripes simply venting their anger at capitalism. (Smith 2014)

Thus a very significant variety of groups joined together to fight for a common purpose, namely halting the advance of what was perceived as a menace to individual and social civil rights emanating from the advancement of late capitalist institutions and practices.

The feat of such a diverse amalgam fighting for a common cause responds to what recently Nina Glick-Schiller has defined as the 'sociabilities of emplacement'. Taking her cue from Georges Simmel to define sociabilities as "social relations that provide pleasure, satisfaction and meaning, a sense of being human" (2016: 4), Glick-Schiller defines "sociabilities of emplacement' as groups of people who "whatever their differences ... can come together not because they tolerate or value difference or otherness but around domains of commonality that include a mutual desire for belonging and justice and a sense of shared humanness" (Glick-Schiller 2016: 4). 
The desire to belong in a fairer and eco-tuned global world became virtually universal in Seattle those days, where even initially disengaged neighbors ended up endorsing the protests in defense of the global community's rights. Such became the dimensions of the 'sociabilities of emplacement' created in Seattle.

In this sense, although the narrative in Your Heart focuses on a limited number of characters, it can be defined as a choral novel, given that the multitude, in the sense expressed by Hardt and Negri $(2000,2005)$ is a vocal presence throughout, and that collective protest is its core leitmotif. Through its focus on the experience of several characters picked from the multitude, the condemnation of injustices in a broad sense is foregrounded, as through remembrance of individual experiences the text manages to capture different forms of socio-political, industrial, work, trade, class and gender injustices taking place in different locations and contexts, especially on the American continent. Forms of injustice denounced by the novel include the use of pesticides in the cultivation of Peruvian bananas, the disappearance of people in Guatemala and women in Ciudad Juarez, Mexico, the abusive gas prices in Peru and Bolivia, the extended practice of outsourcing, and the US sweatshop factories along the border with Mexico, constantly profiting from cheap labor from the neighboring country, among others.

However, Your Heart is more than a political pamphlet listing a succulent catalogue of injustices. It took Yapa ten years to write the novel, and this shows in its meticulously poetic style. One of the text's merits is that it aligns geopolitics with personal and even intimate feelings and emotions.

The novel is articulated around the emotional and political development of Victor, who like the author himself (Yapa is the son of an American mother and a Sri Lankan father) is a biracial young man: the biological son of an Afroamerican mother and an unknown white man. Victor's mother married Victor's adoptive father, also white, and the three of them led ordinary, happy lives until the mother's early death. At this point, Victor was entering adolescence, and he started to irreversibly distance himself from his father, a process which reached a climactic moment the evening when his father set on fire the books Victor had inherited from his mother. The father was worried that they would inspire dangerous ideas in the boy. As Victor stared terrified at the burning pile of books, his father exclaimed: "This is what happens when you care too much" (78). If both the scene of the burning library and the father's opaque comment present a preternatural 
quality, it all gains meaning if we consider that the books Victor received from his mother were the works of Frantz Fanon, Paolo Freire, Che Guevara, James Baldwin, Eduardo Galeano, and other political thinkers. And it makes still more sense bearing in mind the fact that Victor's father is Chief Bishop, the Chief of Police of the city of Seattle, who since his wife's death and throughout the novel is shown to be deeply preoccupied with hardening his son against the world's injustices, lest he suffer too much: "Son ... suffering is everywhere. I see it every day. And if you wear your heart on your sleeve, the world will kill you cold" (26). The verdict "The world will kill you cold" becomes one of the refrains repeated through the narrative, like political slogans chanted by the multitude such as "This is what democracy looks like," "The people united will never be divided," "The whole world is watching," or "What do we want? Justice! When do we want it? Now!"

As his father burns his books, Victor decides to leave the household and start travelling the world, mostly South America. Except for the occasional postcard, Victor will disappear from his father's life. This is the compromised situation the novel begins with: a son and a father completely estranged from each other, and who will end up fighting in opposed factions in an unexpected battle. Victor will join the peaceful protesters, and his father, the Chief of Police, will end up using aggressive dissuasion techniques against the multitude, among whom is his own son. Other characters singled out are the activists Kingfisher (a young' woman's nickname) and John Henry, both of whom involve Victor in the protest. They also present an interesting degree of complexity, especially King. Then there are the police officers Julia and Park, who are used as devices to explore the complexity of the human sense of duty vs. free will; and Charles Wickramasinghe, the Deputy Minister of Finance and Planning of Sri Lanka, a figure laid out as representative of the delegates of the economically disadvantaged countries summoned at the WTO meetings. That chapters should alternate their focus on each of these characters is meaningful in terms of the work's politics and poetics: it emphasizes the assumption that they represent the multitude and enhances the choral effect.

\section{Literature and the Ethics of Care}

The story, which unfolds in a single day, reads as a symphony of diverse notes and tones which gradually gain momentum. The unifying element of these sundry notes is love. The novel compounds a reflection around the 
crucial preoccupation that humans have for other human beings and about their innate capacity to love them. Yapa is vocal about this principle. As he has expressed in an interview:

We're exhausted by our own anger and outrage and looking for reconciliation, looking for something beyond the anger, whatever that might be. In the book I suggest it's human connection. "Love" is so overused, but yes, it's that agape love for your fellow human being. Che Guevara said that the true revolutionary is guided by a great feeling of love. I'm right there with Che. (Patrick 2016)

It is ironic that this analysis of love, so close to the concepts of empathy and care as I shall argue in this paper, should be carried out precisely through the representation of violence. In this sense, the novel raises questions about the complexity of human behavior, and is openly concerned with denouncing the violence put in practice by the forces of order during the Battle of Seattle. Yapa himself has insisted that he has written "a book about police brutality" (Patrick 2016). Without discarding this particular agenda, it is interesting to discuss the ethical component which directs Yapa's literary effort, since besides its testimonial value here rests the novel's worth: Its main preoccupation is interrogating the innate impulse to care for the Other that governs human existence, a concern which responds to what has been termed 'the ethics of care'.

As opposed to a morality based on the traditional Kantian universal norms or principles, which gave origin to what is known as the ethics of justice, an ethics which holds abstract principles as the motor of human behavior, or on the ethics of virtue, which also focuses on the individual subject - the Self -, the ethics of care is a relational guide, directed by the consciousness of the need to pay attention to other human beings - the Other -. The central focus of the ethics of care is, precisely, "on the compelling moral salience of attending to and meeting the needs of the particular others for whom we take responsibility" (Held 2006: 9). Thus, this ethics,

is based on an understanding of the world as a network of relations where we are immersed, and where the acknowledgment of our responsibility towards the others emerges. For [the ethics of care] ... the compromise towards the others is understood as an action taking the shape of help. The subject has the obligation to help the others; if we see a necessity, we feel obliged to contribute to solving it. (Alvarado 2004: 32; my translation) 
This ethics, or rather, its scientific acknowledgment, has its origin in the research carried out by psychologist Carol Gilligan in her ground-breaking study In a Different Voice: Psychological Theory and Women's Development (1982), which revealed that women tend to have an ethical perspective characterized by interpersonal relations, and not by abstract rules or principles, as Kantian ethics would have it. It was Gilligan who baptized this moral perspective, which is of course as old as humanity itself, as the ethics of care. Her discoveries coincided broadly in time with those of Sarah Ruddick, who two years before had published the article "Maternal Thinking" (1980), inaugurating a line of thought which she would later on expand in her book of the same title (1989). According to Ruddick, mothering is a practice which necessarily involves three elements: the preservation of the child, the concern for her or his adequate growth, and the education in values which will make her or him acceptable within the community. In other words, mothering entails the satisfaction of basic needs for the survival, well-being and full integration of the child in society, and together with them, "the unity of reflection, judgement and emotion that arises in relation to these demands" (Baraiter 2011: 62). In her book, Ruddick goes on to defend the necessary application of these principles to the whole of humankind, and their replacement of the patriarchal, hierarchical, powerbased and often militarized systems which govern modern societies, with a view to improve the conditions of human existence. Ruddick's ideas are very close to what Gilligan and later scholars defend under the corollary 'ethics of care', which is preoccupied, as against universal laws or virtues, by elements such as diversity, context, and particularity, where the moral development of the subject turns around specific - not abstract - responsibilities and relations (Gilligan 1985: 42).

It is important to point out that later works have emphasized that the attention paid to human relations and care is not exclusive to women, although it is mostly present in women and in minority and excluded groups (Cortés Pérez 2011: 3), where feelings of solidarity tend to appear more easily than in dominant groups, frequently male. Ruddick herself stipulated that both men and women can be mothers (1989: 40). Interestingly, care expands beyond human beings, and it has also been defined as "a species activity that includes everything that we do to maintain, continue, and repair our 'world' so that we can live in it as well as possible. That world includes our bodies, ourselves, and our environment, all of which we seek to interweave in a complex, life-sustaining web" (Fisher \& Tronto 1990: 40; Tronto 1993: 103). This is especially relevant in connection to the multiple 
fronts which the protesters defended in Seattle, where ecological concerns were a crucial aspect to be cared about. Virginia Held also purports that care goes beyond the mere biological: "all care involves attentiveness, sensitivity, and responding to needs. Needs are of innumerable subtle emotional and psychological and cultural kinds, as well as of completely basic and simple kinds, such as for sufficient calories to stay alive" (Held 2006: 38).

A bone of contention in the development of the Ethics of Care is between the understanding of care as an attitude or as an activity. Nel Noddings, another originator of the discipline, distinguishes between 'caring about', meaning having ideas or intentions to care for others, and 'caring for', which is the actual labor of taking care for others (Noddings 1984). Virginia Held also addresses both forms in her considerations: "I think ... of care as practice and value" (2006: 39), deeming both as necessary aspects of a common ethical and behavioral frame. This is the approach sympathized with in this article, where the notions of care, love, empathy and compassion, though differently nuanced in the history of ethics, are considered as contiguous.

Care, love, empathy and compassion are ways of naming the human affect, which nurtures the desire to provide support for the Other. They are connected to a Levinasian ethics where subjectivity is conditioned by the acknowledgment of the existence of the Other. They all point to the idea of concerned attention towards fellow human beings, and subsequently towards taking active care of them. Literature is probably the most powerful and ubiquitous reverberator of these affects. For writer David Foster Wallace, for instance, "awareness must move always in an outward direction, away from the self" (Smith 2009: 268; qtd. in Ropero 2017: 133). In his address to graduate students delivered in 2005 at Kenyon College, This is Water: Some Thoughts, Delivered on a Significant Occasion, about Living a Compassionate Life, Foster Wallace emphasized the importance of living a life infused with love and care:

The really important kind of freedom involves attention, and awareness, and discipline, and effort, and being able truly to care about other people and to sacrifice for them, over and over, in myriad petty little unsexy ways, every day. That is real freedom. The alternative is unconsciousness, the default-setting, the 'rat race' - the constant gnawing sense of having had and lost some infinite thing. (Wallace 2009: 7-8)

Foster Wallace suggests here that without love and care human beings are incomplete, debased, less-than-human. Literature, characterized by an in- 
trinsic concern for exploring otherness, favors the development of the kinds of freedom Foster Wallace refers to. It promotes an essential qualitative leap, as Zadie Smith puts it, "from solipsism into commonality" (Smith 2009: 283, qtd. in Ropero 2017: 133). Not long ago, former US President Barack Obama emphasized the importance of this capacity in the present state of affairs: "At a time ... when so much of our politics is trying to manage this clash of cultures brought about by globalization and technology and migration, the role of stories to unify - as opposed to divide, to engage rather than to marginalize - is more important than ever" (Kakutanijan 2017). In the same interview, Obama points out that literature manages to bring human beings closer to one another, as it vivifies their relationships and mutual knowledge. Literature has also the capacity to communicate like no other art or craft the precariousness of human existence, and in this way it conveys in a unique manner the necessity of mutual care.

This innate will to take care of other human beings is explored in Your Heart through all of its characters. They are all driven by the same impulse towards the Other, even if this impulse sometimes takes unexpected shapes, such as the police's aggressive stance. Yet quite awkwardly also the police officers are sometimes seen to be moved by the desire to contribute to the general good of society. An outstanding example of this ambivalence is Officer Timothy Park. He is the most ambiguous character, an athletic policeman who acts brutally towards Victor, but who yet happens to be an anonymous hero who in the past saved the lives of thirty-five children dragging them out of a building in flames. Park shows that the line dividing altruism (which here we hold to qualify as love) from the sense of duty is sometimes extremely thin. Remembering the Alfred P. Murrah attack in Oklahoma, where he saved those children, Park still wonders how such horror could have been allowed, and he is sure that a similar thing will not happen in Seattle, "because here he was taking care of that" (248). It is not altogether clear whether his rejection of violence is genuine or owes to his commitment as a policeman. But it could also be the case that the latter is a result of the former: that he chose to be a policeman in order to take better care of the people. In any event, Park is ironically moved by the desire to help, to take care. When he believes Chief Bishop is in trouble (in what turns out to be a huge misunderstanding, because Victor is running towards his father only to talk him out of gassing peaceful protesters, and does not intend to attack him in the least), we are told that Park "would protect his Chief. Because that's what a good cop did" (249), and he attacks Victor viciously. Indeed, 
while Park is willing to help, he is shown to lack empathy, and the irony is that he ends up nearly killing Victor.

Of course, there are drawbacks to a type of care which neglects the people's integrity and their freedom. Elsewhere in the text we read that policemen "carry the burden of protecting people against themselves ... [and do so] willing to protect people from their own stupidity", for which purpose they are "willing to be the bad guy" (52). However, violence, of any kind but most eloquently physical violence, is the dividing line where the limit between actively caring for the Other and interfering in the Other's integrity and freedom is drawn. Park is a rather arid character who sports a disfiguring scar in his face, and on the whole the reader is not invited to like him. Yet the discovery that he saved those children, the reason for his scar, is revealed in the end, after the reader has developed an aversion towards his violent attitudes. The unexpected discovery of Park's past heroism contributes to the general effect arguably searched by Yapa: showing that nobody is completely free of guilt, nor the opposite, and that even those who make mistakes are often driven by good will and an ethics of care. Having said this, such benevolent interpretation should by no means be confused with an exoneration of police brutality, which in the novel is emphasized once and again. For instance, Chief Bishop's argumentation is similar to that of Park regarding his will to protect the people: "They were his people. And if he had to take away their rights to protect their rights that's exactly what he would do" (229). These are the same parameters as Park's, and are indefensible. According to Virginia Held, an ethics of care "understands those who use violence, even in ways usually considered justifiable, as having morally failed to develop appropriate ways to avoid needing to do so" (Held 2006: 139). Further, these attitudes fall in one of the pitfalls of care according to Joan Tronto: paternalism, "in which care givers assume that they know better than care receivers what those care receivers need" (2010: 161).

Another essential function of literature is substantiating the articulation of subjectivity formations. This articulation, both in reality and in fiction, takes place within socially established parameters. As Judith Butler formulates it, "the self delimits itself, and decides on the material for its self-making, but the delimitation that the self performs takes place through norms which are, indisputably, already in place" (2002: 225). Individuals are never entirely insulated from the world, they exist in relation to those persons who surround them and to their context, and it is within this context that their personal choices are made. In this regard, Your Heart follows Vic- 
tor's development as a new ethic and political subject in the specific context of the turn-of-century American culture in a globalizing world, and of the specific events in Seattle. Victor's is postulated as an archetypal caring subjectivity, which necessarily incorporates his teenage political readings and his travel experiences in America and Asia witnessing injustice.

In 1999 , Victor is 19 years old. On Tuesday November $30^{\text {th }}$ he sees himself dragged into the demonstrations somewhat by chance - as initially he just approaches the protesters in order to try and sell them some substances. At the beginning, he shows an important degree of disaffection with worldly concerns, not empathizing at all with the motives that lead King and John Henry, as fictional spokespersons of the thousands composing the multitude, to their extreme modes of protest against a system they deem unfair. Slowly, however, Victor will align himself with the crowd, and will end up collaborating in earnest in their peaceful battle for a fairer world. In this way, Victor's maturation as a subject is simultaneous with his access into the community and with the awakening of his sense of belonging with them. His development as a subject is thus on a par with that other crucial aspect systematically investigated by literature: the relationship between the subject and the world, and, more particularly, with other human beings. As we have seen, the ethics of care plays a relevant role in this development.

Victor is not numb to the suffering of other human beings; since his childhood he played with his mother what could be called 'the empathy game', which consisted of the attempt at becoming other persons and objects. For instance, sometime in Victor's late childhood they play that they are a banana (122). That feeling of communion with otherness was dormant in Victor after the trauma of his mother's death and the family's disintegration, but in the protests it is gradually reawakened. By the end of the novel, nearly beaten to death by Park and a bunch of anonymous policemen, Victor remembers his mother, recalling how every day since the age of eight until her death he would help her distribute plates of soup to a queue of unemployed men before going to school early in the morning. According to the author, this memory is paramount in the novel; it is "the heart of the book. Victor learns from his mom in that soup kitchen that complete strangers can be your blood kin" (Patrick 2016). That the others are his blood kin, further, that they live within him: Victor re-discovers this feeling of absolute empathy only in the very last pages, when his father has eventually picked him and is holding him in his arms. The metaphor of a total communion with the Other becomes literal when in Victor's dying delirium, 
held by his disconsolate father, he feels that his own body is a building with many staircases and spaces, where all his fellow human beings carry on with their little daily routines. At this point he feels so much part of the others that the others are contained within him, such is his feeling of empathy. Far from his initial - seemingly - disaffection, what Victor finally is seen to entertain for the Other is love. Love is the crucial word, the word which, not casually, closes the novel. It is the ultimate mission Victor comes to accept, the culmination of his ethical education.

\section{Care and the Border-Crossing Multitude}

As suggested above, Kingfisher and John Henry are the spokespersons of the multitude, a multitude guided by love and the drive to care for the Other. But so are Park (in his own, bizarre manner) and Victor (through his late realization of love). Also the policewoman Julia, and even Charles Wickramsinghe, the Sri Lankan delegate caught in the protest, represent the multitude in different ways. The multitude is one, but it has many voices. As foregrounded in the introduction, heterogeneity is its substance matter. The slogan "We seek a world in which there is room for many worlds" (72), displayed in a banner on the San Francisco Golden Gate six months before the Seattle protest and originating in the Zapatista movement in Mexican Chiapas in the early 1990s, points to the constituent heterogeneity of humankind, hence of the multitude: "A multitude is irreducible multiplicity; the singular social differences that constitute the multitude must always be expressed and can never be flattened into sameness, unity, identity, or indifference," contend Hardt and Negri (2005: 105). It is precisely this heterogeneity that makes the multitude all the more productive and successful:

the members of the multitude do not have to become the same or renounce their creativity in order to communicate and cooperate with each other. They remain different in terms of race, sex, sexuality and so forth. We need to understand, then, the collective intelligence that can emerge from the communication and cooperation of such varied multiplicity. (Hardt and Negri 2005: 92)

The emphasis on diversity and difference (Bhabha 1995) amounts to disengage the perception of the multitude from older notions of the 'crowd', where great masses of people brought together were seen as anonymous and inherently destructive (Reicher 2004). Together with heterogeneity, the other constituency of the characters designed by Yapa is in-betweenness, 
namely, a propensity to cross or be across borders. As has been noted by scholars, there is an increasing tendency "to construct the border crosser or the hybrid ... into a new privileged subject of history" (Pablo Vila 2003; quoted. in Naples 2010: 505; italics in the original). It is not coincidental that Victor should be a child of mixed descent: he is, quite literally, the emerging protagonist of a new type of history, made by the ordinary people, by people who care. And like him, in one way or another all the characters singled out from the multitude are made to stand in-between, they are purposeful trespassers. Even Chief Bishop can be seen to cross borders when by the end of the novel he decides to resign his position as Chief of Police and thus cross the line to the other side, that of the ordinary people who can choose their path according to their own ethical standards and whose free will is not sequestered by any disciplinary institution.

As a police officer, Guatemala-born Julia has her free will sequestered. But perhaps because she is bicultural, or because she is a woman, or simply because she is human, she has ethical quandaries over her role as a disciplinarian. These scruples are not new to her: she had served in Los Angeles during the Rodney King riots in 1992, and decided to leave the city after she had to participate in repressing the protesters. Yapa has stated about Julia that "all through the book she's trying to negotiate between her profession and her humanity" (Patrick 2016). As the novel concludes, Julia shoots Kingfisher with a rubber ball weapon, hurting her badly. She does so apparently in self-defense, but also because that is what a good policewoman "was trained to do" (292). Yet when she sees that King begins to bleed copiously, and when she then notices that Park and other policemen are savagely beating Victor "like a pack of dogs who have lost their minds in fear and rage" (293), Julia realizes that she needs to stop that barbarity, as she should have done all those years before in Los Angeles. Concern for her fellow human beings guides her, and she gathers strength to "remember that they are not dogs, but men. Frightened and angry human beings" (294). She eventually manages to stop the unnecessary carnage. She does so, however, at the expense of being detained herself and "being led away in cuffs" - albeit "for doing the right thing" (300). Like all the other characters, Julia is a heroic trespasser of her own kind.

Kingfisher is a twenty-seven years old white woman whose wish to close the WTO is a symptom of her desire "to end the suffering which was the world without end" (241). She appears indeed as the paradigmatic demonstrator, guided by genuine concern for the Other: 
She believed in the power of love. Love was the animating force that filled her body. She let it move her arms, her legs, her lungs. It was love that governed the workings of her mouth, the words called forth from her larynx.... She was not afraid to take the gas - it was just that in some way her love for these people made her want it not to be so goddam necessary. (73)

The irony is that she keeps a dark secret, one which is at odds with her philosophy of love and care for the Other: some years before she killed a person. When she was obliged to cross the border from Mexico undocumented, and in order to protect a defenseless child and his father who were travelling with her, she shot an old man who was menacing them with a weapon. Although she feels it was in a way necessary, King feels deep sadness about this killing. She is still astounded at the enormity of it, and the episode remains a watershed in her life: "How could a human life, a thing so layered and vast it was a world unto itself, be reduced so quickly and completely to a cold corpse beneath the trees?" (241). In Seattle, she is secretly preoccupied that if she is detained in the demonstrations, she will be found out and accused of that murder. This character shows again that the notions of innocence and guilt are often muddled, and that it is not always easy to discern between these two apparently antagonistic extremes.

That King should be shot by Julia is not accidental either. It is part of a distorted mirror game between two women who are fighting for the opposing sides and who yet share the need to care for the Other next to them. After shooting King, being shot, Julia realizes that it is high time to put an end to this pandemonium. Meanwhile King is taken away in an ambulance. Badly hurt and in deep pain, in a fit of pathos she asks the medic to let her die at this point. By contrast to her plea, the scene provides a blunt example of the ethics of care, when in response the medic takes her hand in his and looks at her closely:

in his eyes she saw not the state, not institutionalized evil, not modern medicine and all its medical compromises ... no, what she saw in his eyes, in his face, was nothing more than simple human concern, the sudden affection of one human being for another. (295)

This is a silent exchange which foregrounds "the relatedness of human beings, built and rebuilt, that the ethics of care is being developed to try to understand, evaluate, and guide" (Held 2006: 30). 
Another character who both deploys an ethics of care and is seen to cross borders is the fictitious Minister of Finance and Planning of Sri Lanka, Sir Charles Wickramsinghe. His political sympathies lie first with an institution which can supposedly ease life for his fellow citizens, but then it shifts towards the multitude of demonstrators, who despise that institution and who appear to be right in their criticisms. Like the rest, Wickramsinghe is characterized by a genuine concern for others: he has spent years flying from one country to another determined to obtain all the signatures necessary for Sri Lanka to become a member of the WTO. He is rather obsessed with helping his fellow citizens through the opportunities, he believes, that this membership will provide. However, as Yapa remarks, "this is a man who knows how to listen" (Patrick 2016), and he also becomes a trespasser. When he is mistakenly detained by the police and forced into a bus where other detainees are kept, Wickramsinghe reacts calmly, and in a wise strategic move he takes the chance to ask the protesters their reasons for such staunch opposition to the WTO. Old enough to have been educated in a colonial medium, this seasoned politician is fully aware of the inequalities of such a system, and also of the structural inequalities perpetuated in a supposedly post-colonial world. Therefore, what he hears from the protesters comes as no surprise to him. He realizes then that his position is one in-between from the beginning, since although he is one of the delegates, thus a member of the governing elites, he is on the trailing wagon, as a representative of one of the poor countries which have much to lose in a globalized world where laws are dictated by the powerful countries. After carefully listening to the detainees' arguments, Wickramsinghe sides with them and makes a decision:

He was going to shut down the entire round of meetings and make sure they didn't start until they started on fair terms....he was going to gather enough of the African ministers, the Latin American ministers, the Asian ministers, and together they were going to make the meetings fair and transparent. Environmental regulations. Labor laws.... Fair trade, not free trade. (289-290)

In the novel's conclusion, fiction reproduces tersely what came to happen for real in the Battle of Seattle:

By Friday night all the powerful First and Third World environment, development and human rights groups were condemning the way the talks were being powered through by the Americans to protect their own trading interests... And more than 40 African, Carib- 
bean and Latin American countries had united in protest against the way poor countries were being bullied by the rich and the way their concerns were being marginalised.

An unprecedented rebellion was in the offing.

With just hours left before the talks were scheduled to conclude ... the WTO secretariat went into panic mode. Press conferences, briefings and backroom discussions were cancelled. ... For the first time in history the poor countries of the world had told the rich they weren't playing the First World's game. (Vidal 1999)

It seems that, without considering later historical developments (let alone the political climate in the US and around the world at the time these lines are written), with the joint effort of thousands of demonstrators and some dozens of delegates from the so-called Third World countries, the Battle of Seattle was won, all in all, by the people - if only temporarily.

This broad display of border crossings has important implications. In particular, the metaphorical crossing and deconstruction of borders between the Self and the Other which an ethics of care implies should not be neglected. Together with these, care ethicist Joan Tronto has rejected other hierarchical distinctions elaborated by traditional systems of Western thought, such as those between the public and the private, the political and the ethical, and the abstract/impersonal vs. the particular observer. In this vision, which revitalizes long despised Indigenous epistemologies based on an interrelated living world comprised of a variety of forms (of which humankind is but one), binaries and hierarchical divisions need to be questioned and complicated in favour of a new understanding of human life where relationality is at the center:

The ethics of care calls for the transformation of the different segments of society, with caring values and cooperation replacing the hierarchies and dominations of gender, class, race, and ethnicity. ... But in addition to transforming each of such given domains, the ethics of care would transform the relations between domains. (Held 2006: 160)

This explains Yapa's systematic choice to depict in-betweeners and trespassers. A new world with truly fair and democratic structures like the one proposed by the Seattle protesters, not based on economic gain, power accumulation and continuous militarization, requires that hierarchies be questioned and trespassed, with a view to eventually undoing them. 


\section{Conclusion}

The ethics of care guides this reading of a novel which is imbued in such a worldview. The links between care ethics and global politics has been sufficiently explored by now (Sevenhuijsen 1998, Robinson 1999, Noddings 2002, Engster 2007, Tronto 2013), and this is a perspective which keeps thriving. Your Heart is a step forward in the cultivation of more caring forms of consciousness. Literature is indeed a form of care. As Sunil Yapa has claimed, "Empathy is a profound act of imagination and human connection. In fiction, we imagine ourselves into other people's experiences. Of course, another word for that is "reading"' (Patrick 2016).

Your Heart is a politically engaged novel which foregrounds the power of the multitude, of the ordinary people, in a world which is increasingly more controlled by anonymous powers privileging economic gain at the expense of the well-being of the citizens. A sophisticated narrative, its strength lies in its putting poetic language at the service of a political cause. The novel bears witness to what happened in the so-called 'Battle of Seattle', the fiveday confrontation between pacific protesters and forces of order in Seattle in 1999, when the former attempted, and to a great extent managed, to stop the scheduled meetings of the World Trade Organization. This work highlights the heterogeneity and in-betweenness of the demonstrators, and is thus faithful to the complex diversity of politics lying underneath the commonality of the protests. The narrative is focalized on a plurality of characters, and purposefully refuses to render any of them particularly prominent - with the exception, perhaps, of Victor, thus adding a layer of literary meaning which enables possible readings of Your Heart as a traditional bildungsroman or coming-of-age narrative. This plurality emphasizes, as I have shown, the power of the multitude, which ceases to be a menacing, unproductive mob and becomes an actual agent of social change. The fact that Victor comes near death but eventually survives, in the process awakening his father's social consciousness, is a powerful metaphor for hope; for the hope that no matter how bleak the situation appears to be in a world dominated by stringent capitalism and reactionary politicians, things can change for the better.

The "Battle of Seattle" protesters were attempting to curtail a world dominated by hierarchical systems that favor deeply oppressive economic practices. The proposal, by both the Seattle protesters and Yapa, is to replace such structures with a new, truly democratic relationality, an ethics of care which puts human beings and their needs at the center - without neglecting 
care for the planet. Sunil Yapa closes ranks with the foremost critics of corporate capitalism when he chooses to finish the list of acknowledgements by quoting nearly verbatim from Arundhati Roy's speech Come September, which she gave on the first anniversary of the 9/11 attacks - an impending catastrophe by the time of the 'Battle of Seattle'. According to Roy, and repeated in Your Heart is Muscle the Size of a Fist, "Another world is not only possible, she's on her way. Maybe many of us won't be here to greet her, but on a quiet day, if I listen very carefully, I can hear her breathing."

\section{Works cited}

Alvarado García, Alejandra. 2004. "La Ética del Cuidado". Aquichan 4 (4): 30-39.

Baraitser, Lisa. 2011. "Sara Ruddick, 1935-2011: A Mother's Thought". Radical Philosophy 167: 62. https://www.radicalphilosophy.com/obituary/sara-ruddick-1935\%E2\%80\% 932011. Accessed 02/03/2017.

Bhabha, Homi K. 1995. "Cultural Diversity and Cultural Difference.” In The Post-Colonial Studies Reader, ed. B. Ashcroft, G. Griffiths, H. Tiffin. London: Routledge, pp. 206-212.

Butler, Judith. 2002. "What is Critique?: An Essay on Foucault's Virtue." In The Political, ed. by David Ingram. London: Wiley-Blackwell, pp. 212-226.

Charles, Ron. 2015. "A novelist's soul-searching rewind to the 1999 eruption on Seattle's streets." The Washington Post December 29, 2015. https://www.washingtonpost.com/ entertainment/books/a-novelists-soul-searching-rewind-to-the-1999-eruption-on-seattles-streets/2015/12/29/e841a6e0-a7f6-11e5-8058-480b572b4aae_story.html?tid=kp_ google\&utm_term=.696f88263356. Accessed 02/03/2017.

Cortés Pérez, Sol Angy. 2011. "El cuidado como objetivo político-social, una nueva mirada desde la ética del cuidado." Los actores de las políticas sociales en procesos de transformación. Universidad pública de Navarra.

http://www.unavarra.es/digitalAssets/158/158837_6_p-CortesPerez_eticadelCuidado.pdf. Accessed 02/03/2017.

Ditum, Sarah. 2016. "Your Heart Is a Muscle the Size of a Fist by Sunil Yapa review - in the thick of leftwing activism." The Guardian 3 March 2016. https://www.theguardian. com/books/2016/mar/03/your-heart-is-a-muscle-the-size-of-a-fist-sunil-yapa-review." Accessed 02/03/2017.

Engster, Daniel. 2007. The Heart of Justice. Oxford: Oxford University Press.

Fisher, B. \& Tronto, J. (1990) 'Toward a Feminist Theory of Caring.' In Circles of Care, eds. E. Abel \& M. Nelson. Albany: SUNY Press,, pp. 36-54.

Gilligan, Carol. 1982. In a different voice: Psychological Theory and Women's Development. Cambridge, MA: Harvard University Press.

Glick-Schiller, Nina. "Studying Unevenness: A Multiscalar Conjunctural Approach.” ResearchGate.

https://www.researchgate.net/publication/312299128_Studying_Unevenness_A_Multiscalar_Conjunctural_Approach. Accessed 01/03/2017.

Hardt, Michael and Antonio Negri. 2000. Empire. Cambridge, MA: Harvard University Press.

-.2005. Multitude: War and Democracy in the Age of Empire. London: Hamish Hamilton. 
Held, Virginia. 2006. The Ethics of Care: Personal, Political, and Global. Oxford: Oxford University Press.

Hendrix, Jenny. 2016. "Your Heart Is a Muscle the Size of a Fist, by Sunil Yapa."

The New York Times Sunday Book Review Jan 152016. https://www.nytimes.com/2016/01/17/ books/review/your-heart-is-a-muscle-the-size-of-a-fist-by-sunil-yapa.html. Accessed 02/03/2017.

Holden, Stephen. 2008. "When Worlds Collided by Puget Sound. Battle in Seattle, directed by Stuart Townsend." The New York Times Sept 18 2008. http://www.nytimes. com/2008/09/19/movies/19seat.html. Accessed 02/03/2017.

Kakutanijan, Michiko. 2017. "Barack Obama's Secret to Surviving the White House Years: Books." The New York Review of Books Jan 16 2017. https://www.nytimes. com/2017/01/16/books/obamas-secret-to-surviving-the-white-house-years-books.html ?hp\&action=click\&pgtype $=$ Homepage $\&$ clickSource $=$ story-heading $\&$ module $=$ b-ledepackage-region\&region=top-news\&WT.nav=top-news. Accessed 18/01/2017.

Kumar, Amitava (ed.). 2002. World Bank Literature. Minneapolis: University of Minnesota Press.

Limprecht, Eleanor. 2016. "Your Heart Is a Muscle the Size of a Fist: A Social Novel Like a Protest." The Sydney Morning Herald Jan 28 2016. http://www.smh.com.au/entertainment/books/your-heart-is-a-muscle-the-size-of-a-fist-review-a-social-novel-like-a-protest-20160122-gmboow.html Accessed 02/03/2017.

López-Ropero, Lourdes. 2016. "Searching for a 'Different Kind of Freedom': Postcoloniality and Postfeminist Subjecthood in Zadie Smith's NW." Atlantis: Journal of the Spanish Association of Anglo-American Studies 38 (2): 123-139.

Mountford, Peter. 2011. A Young Man's Guide to Late Capitalism. Boston: Houghton Mifflin Harcourt.

- . 2014. The Dismal Science. Portland: Tin House.

Naples, N. A. 2010. "Borderlands Studies and Border Theory: Linking Activism and Scholarship for Social Justice." Sociology Compass 4: 505-518.

Newman, Robert. 2003. The Fountain at the Centre of the World. New York: Verso.

Noddings, Nel. 1982. Caring: A Feminine Approach to Ethics and Moral Education. Berkeley, CA: University of California Press.

- . 2002. Starting at Home: Caring and Social Policy. Berkeley, CA: University of California Press.

Oldham, Kit. 2009. "WTO Meeting and Protests in Seattle (1999)" HistoryLink.org Essay 9183. http://www.historylink.org/File/9183. Accessed 15/01/ 2017.

Patrick, Bethane. 2016. "Sunil Yapa: 'Empathy is a Radical Act'." Literary Hub, January 27 2016. http://lithub.com/sunil-yapa-empathy-is-a-radical-act/\#. Accessed 15/01/2017.

Reicher, Stephen David. 2004. "The Psychology of Crowd Dynamics”. In Self and Social Identity, ed. M. Brewer and M. Hewstone. London: Blackwell.

Robinson, Fiona. 1999. Globalizing Care: Ethics, Feminist Theory, and International Relations. Boulder, CO: West View Press.

Rowley, Rick and Jill Friedberg. 2000. This Is What Democracy Looks Like (documentary). Roy, Arundhati. 2002. Come September. Lecture delivered at the Lensic Performing Arts Center. September 29, 2002. http://www.lannan.org/images/cf/arundhati-roy020918-trans-read.pdf. Accessed 14/03/2017.

Ruddick Sara. 1980. "Maternal Thinking." Feminist Studies 6 (2):342.

-. 1989. Maternal Thinking: Towards a Politics of Peace. Boston: Beacon Press.

Sevenhuijsen, Selma. 1998. Citizenship and the Ethics of Care. New York, NY: Routledge. 
Schaub, Michael. 2016. “'Your Heart Is A Muscle' Is A Florid, Ambitious Tale Of Protest.” Jan 12 2016. npr books.

http://www.npr.org/2016/01/12/462263265/your-heart-is-a-muscle-is-a-florid-ambitioustale-of-protest. Access 02/03/2017. Accessed 02/03/2017.

Scholes, Lucy. 2016. "Your Heart Is a Muscle the Size of a Fist, by Sunil Yapa: Streetwise Tale Set in Seattle's Moment of Rage." Independent.

http://www.independent.co.uk/arts-entertainment/books/reviews/your-heart-is-a-musclethe-size-of-a-fist-by-sunil-yapa-book-review-streetwise-tale-set-in-seattles-a6861611. html. Accessed 02/03/2017.

Smith, Noah. 2014. "The Dark Side of Globalization: Why Seattle's 1999 Protesters Were Right." The Atlantic Jan 62014.

https://www.theatlantic.com/business/archive/2014/01/the-dark-side-of-globalization-whyseattles-1999-protesters-were-right/282831/. Accessed 15/01/ 2017.

Smith, Zadie. 2009. "Brief Interviews with Hideous Men: The Difficult Gifts of David Foster Wallace." Changing my Mind: Occasional Essays, pp. 257-300. London: Penguin.

Solnit, David and Rebecca Solnit. 2009. The Battle of the Battle of Seattle. Chicago: AK Press.

The New Yorker. 2016. "Briefly Noted." Jan 25 2016. http://www.newyorker.com/magazine/2016/01/25/briefly-noted-your-heart-is-a-muscle-the-size-of-a-fist. Accessed 02/03/2017.

Thompson, Rustin. 2000. 30 Frames a Second: The WTO in Seattle. White Noise Productions.

Townsend, Stuart. 2007. Battle in Seattle (film).

Tronto, J. C. 1993. Moral Boundaries: A Political Argument for an Ethic of Care. New York: Routledge.

-. 2010. "Creating Caring Institutions: Politics, Plurality, and Purpose, Ethics and Social Welfare," 4 (2): 158-171.

-. 2013. Caring Democracy: Markets, Equality, and Justice. New York: New York University Press.

Vila, Pablo. 2003. Ethnography at the Border. Minneapolis: University of Minnesota Press.

Vidal, John. 1999. "Real Battle for Seattle." The Guardian Dec 5 1999. https://www.theguardian.com/world/1999/dec/05/wto.globalisation. Accessed 01/03/2017.

Wallace, David Foster. 2009. This Is Water: Some Thoughts, Delivered on a Significant Occasion, about Living a Compassionate Life. New York: Little, Brown and Company.

Winik, Marion. 2016. "Your Heart is a Muscle the Size of a Fist by Sunil Yapa." South China Morning Post Jan 232016.

http://www.scmp.com/lifestyle/books/article/1902810/book-review-your-heart-musclesize-fist-sunil-yapa. Access 02/03/2017.

Yapa, Sunil. 2016. Your Heart is a Muscle the Size of a Fist. Little, Brown, MA: Lee Boudreaux. 